\title{
Evaluation of urinalysis parameters and antimicrobial susceptibility of uropathogens among out-patients at University of Cape Coast Hospital

\author{
James K. Prah ${ }^{1}$, Samuel Amoah ${ }^{1}$, Dickson WK Ocansey ${ }^{1}$, Rudolf Arthur ${ }^{1}$, Emmanuel Walker ${ }^{1}$ and \\ Dorcas Obiri-Yeboah ${ }^{2}$
}

Ghana Med J 2019; 53(1): 44-51 http://dx.doi.org/10.4314/gmj.v53i1.7

\author{
${ }^{1}$ University of Cape Coast Hospital, University of Cape Coast, Ghana \\ ${ }^{2}$ Department of Microbiology and Immunology, School of Medical Sciences, College of Health \& Allied \\ Sciences, University of Cape Coast, Ghana
}

Corresponding author: James K. Prah

E-mail: james.prah@ucc.edu.gh

Conflict of interest: None declared

\section{SUMMARY}

Background: Urinary tract infection (UTI) is a major global public health issue. The gold standard for diagnosing UTI is urine culture. This is however labour intensive and time consuming. Many prescribers therefore rely on urinalysis in diagnosing UTI. This study sought to evaluate the performance of some parameters of urinalysis as predictors of urine culture positivity. The common causative agents and their antibiotic susceptibility patterns were also determined.

Methods: A cross sectional study was carried out at the University of Cape Coast Hospital from July 2017 - December 2017 among out-patients. The performance characteristics of leukocyte esterase (3+) and nitrite reactions were estimated and compared with urine culture. Antimicrobial susceptibility tests were done using disc diffusion technique described by Kirby-Bauer.

Results: Prevalence of UTI in this study was 30.0\% (64/213). The most prevalent pathogen was E. coli (20, 31.2\%), followed by S. saprophyticus $(9,14.1 \%)$. Most of the bacteria $(52,94.5 \%)$ were sensitive to amikacin, followed by ciprofloxacin $(42,76.3 \%)$. The most sensitive $(94.4 \%)$ of the parameters was pus cells [ $>5$ white blood cells (WBC) per high power field (HPF)] and the least sensitive was the nitrite test $(21.0 \%)$. The leukocyte esterase test showed the highest accuracy of $91.1 \%$.

Conclusion: The study supports the recommendation of the use of oral ciprofloxacin as the first line treatment of uncomplicated UTI by the Ghana Standard Treatment Guidelines (2017).

Funding: No funding was provided for this study.

Keywords: urine tract infection, urinalysis, uropathogens, Cape Coast

\section{INTRODUCTION}

Globally urinary tract infection (UTI) continues to be a major public health issue. It is the second most common type of infection in the human body and the most common bacterial infection. ${ }^{1}$ Each year, about 8.1 million people visit health care providers as a result of urinary tract infections. ${ }^{2}$ In 2014, UTIs accounted for $0.8 \%$ of all admissions in Ghana. ${ }^{3}$ UTIs occur when microbial organisms colonize the urinary tract. Clinically, UTIs are classified as being either uncomplicated or complicated. Urinary tract infections are caused by both Gram-positive and Gram-negative bacteria, as well as by some fungi and viruses. In the diagnosis of urinary tract infections, the gold standard is the detection of the pathogen in urine in the presence of clinical symptoms. ${ }^{4}$ Mid-stream urine is cultured to detect and identify the pathogen.
Internationally, the minimum level of bacteria in urine that demonstrate an infection has not been clearly defined or standardized by microbiological laboratories. ${ }^{5}$ Many laboratories have defined $10^{5}$ colony forming units (cfu) per $\mathrm{ml}$ of urine as the threshold for an infection. Some other researchers recommend that urinary tract infection can be diagnosed from a count of $10^{3} \mathrm{cfu} / \mathrm{ml} .^{5}$ Since culturing urine is labour intensive and time consuming, many physicians rely on urinalysis for rapid diagnostic reports. Urinalysis has three components, physical examination, chemical examination and microscopic examination. Bacteriuria can be detected chemically and microscopically. 
Bacteria in urine are chemically detected when bacteria convert nitrates to nitrites. This biochemical reaction is usually associated with bacteria of the family Enterobacteria.

However other uropathogens such as S. saprophyticus, Pseudomonas species, and Enterococci do not produce nitrite and this limits the usefulness of the test. ${ }^{6}$ The presence of white blood cells (WBCs) in urine can be detected by the use of the leukocyte esterase test. Men normally have fewer than 2 WBCs per high power fields (HPF), whilst women normally have fewer than 5 WBCs per HPF. ${ }^{7,8}$ Some studies have been conducted to evaluate the usefulness of some parameters of urine analysis in predicting urine culture positivity. ${ }^{9,10}$

Chemotherapy has been very useful in the management of UTIs over the years. However, certain practices such as inappropriate dosing and duration of antibiotic therapy and over the counter availability of antibiotics have contributed to the emergence of antibiotic drug resistance among the common pathogens. ${ }^{11}$ Clinicians usually start treating suspected UTIs empirically even before urine culture results are available. Therefore to ensure that drugs prescribed are appropriate, clinicians must have knowledge on the susceptibility patterns of the known common causative organisms to available drugs in their settings. ${ }^{12}$

This is very important because causative agents of UTIs and their susceptibility trends vary in geographical locations, even within the same country. Such patterns may also change with time. ${ }^{13}$ In Ghana, a number of studies have been done to identify the common causative organisms and in some cases the susceptibility patterns in different populations such as pregnant women ${ }^{14}$, infants and people with urinary tract pathologies. ${ }^{15,16}$ However, there is a paucity of data from the present study area, Cape Coast, Ghana on the common causative agents of UTIs and their susceptibility patterns among the general population.

Our search in published literature found no study in our setting that had evaluated the usefulness of urinalysis in the diagnosis of urine tract infection even though clinicians commonly rely on it in the diagnosis of UTI instead of the more laborious and time consuming urine culture. This study therefore seeks to determine the prevalence of local bacteria isolates from suspected UTI out patients and their susceptibility to recommended drugs for use in the treatment of UTIs in the University of Cape Coast Hospital.
The study also ascertained the utility of nitrite test, leukocyte esterase test and the presence of urinary pus cells $\geq 5$ per HPF in the diagnosis of UTI. The findings of this study will be useful in improving the efficacy of empirical treatments of UTI in our setting.

\section{METHODS}

\section{Study population}

This was a cross sectional study carried out at the University of Cape Coast Hospital from July 2017 December 2017.Out-patients irrespective of age and sex sent to the laboratory as suspected cases of UTI for urinalysis were recruited into the study using systematic random sampling technique.

Patients with known factors that compromise their urinary tract or host defense, such as urinary obstruction, urinary retention caused by neurological disease, immunosuppression, pregnancy and the presence of foreign bodies such as calculi, indwelling catheters or other drainage devices were excluded from the study.

If a patient had taken antibiotics within two weeks prior to the study, he/she was excluded as well. Patients were asked to provide a clean catch midstream urine in a sterile screw capped universal container. The medical records of recruited patients were consulted to obtain information on their presenting complaints and past medical history.

Ethical approval for the study was obtained from the University of Cape Coast Institutional Review Board with a protocol ID (UCCIRB/EXT/2017/04). Permission was obtained from the management of the University of Cape Coast Hospital. All respondents gave informed consent.

\section{Dipstick Urinalysis}

Dipstick urinalysis was done using Combur 10-Test M strips with reagent pads for semiquantitative assessment of $\mathrm{pH}$, specific gravity, leukocyte esterase, nitrite, protein, glucose, ketones, urobilogen, bilirubin, and blood. Leukocyte esterase (3+) and nitrite reactions were evaluated as predictive parameters for UTI.

\section{Microscopic Sediment Urinalysis}

Manual microscopic sediment inspection was performed as follows: each urine sample $(10 \mathrm{~mL})$ was centrifuged at $1,500 \mathrm{rpm}$ for $5 \mathrm{~min}$, and the supernatant was removed. At least 20 random microscopic fields were examined at X40 high power field (HPF) for each sample, and the mean number of cells and particles/HPF were calculated.

Bacterial Isolation and Identification Procedures

Isolation of uropathogens was performed by a surface streak procedure on both $5 \%$ sheep blood and 
MacConkey agar (Biomark Laboratories, Pine 411041, India) using $5 \mu \mathrm{L}$ calibrated loops for semiquantitative method and incubated aerobically at $37{ }^{\circ} \mathrm{C}$ for 24 hours, and those cultures which becomes negative at the end of 24 hours incubations were further incubated for 48 hours.

A specimen was considered positive for UTI if a single organism (pure colonies) was cultured at a concentration of $\geq 10^{5} \mathrm{cfu} / \mathrm{ml}$. In instances of mixed bacterial growth, the procedure was repeated with fresh samples of patients. These were done to rule out possible contamination.

Each colony, representing an isolate was picked and subcultured on MacConkey agar to obtain pure culture. Identification of bacteria was done by colonial morphology and standard biochemical tests. ${ }^{17}$ Fungal species were identified based on colonial characteristics and direct wet preparation.

\section{Antimicrobial Susceptibility Testing}

Antimicrobial susceptibility of isolates was performed by the disc diffusion assay on Muller Hinton Agar by KirbyBauer method. ${ }^{17}$ The antibiotic discs and their concentrations were: Augmentin $(30 \mu \mathrm{g})$, Ciprofloxacin $(5 \mu \mathrm{g})$, Ceftriaxone $(30 \mu \mathrm{g})$, Gentamicin $(10 \mu \mathrm{g})$, Piperacilin $(20 \mu \mathrm{g})$, Amikacin $(30 \mu \mathrm{g})$, Nitrofurantoin $(300 \mu \mathrm{g})$, Nalidixic Acid $(30 \mu \mathrm{g})$, Ceftadizim $(20 \mu \mathrm{g})$, Norfloxacin $(20 \mu \mathrm{g})$, Tetracycline $(30 \mu \mathrm{g})$, and Levofloxacin $(5 \mu \mathrm{g})$.

All the antimicrobials used for the study were obtained from Biomark Laboratories, Pine 411041, India. A standard inoculum adjusted to $0.5 \mathrm{McFarland}$ was swabbed on to Muller- Hinton agar (Biomark Laboratories, Pine 411041, India); antibiotic disc were dispensed after drying the plate for 3-5 minutes. The reference strains used as control were $E$. coli (ATCC 25922), S. aureus (ATCC25923) and P. aeruginosa (ATTC 27853). Inhibition zone diameters were measured to the nearest millimeter with a slide gauge and interpreted according to the CLSI guidelines. ${ }^{19,20}$

\section{Data Analysis}

Data collected were entered into Microsoft excel and imported into SPSS version 20.0 for analysis. The data collected included demographic characteristics, clinical presentation, urine culture results, antimicrobial spectrum of resistance and urinalysis results.

For categorical variables, percentages were calculated. Continuous variables were described by means and standard deviations.

The sensitivity, specificity, predictive values (positive and negative) and accuracy for the parameters analyzed as predictors of UTI were calculated using positive urine culture as standard. To investigate any statistically significant association between patients' complaints and culture positivity, chi square test of association was employed. $P$ values, <0.05 were considered significant.

\section{RESULTS}

A total of 213 urine samples were analyzed, $41.7 \%$ were from males and $57.3 \%$ from females. Uropathogens isolated and characterized were 64. These included 55 bacterial and 9 fungal isolates. This results in a UTI prevalence of $30.0 \%(64 / 213)$ in this study population.

The age and sex distribution of patients with UTI according to isolates and presenting complaints are given in Tables $1 \mathrm{a}$ and $1 \mathrm{~b}$ respectively. Majority $(48,75.0 \%)$ of the UTI patients were females indicating a high recovery of bacteria in female samples as compared to males. Most UTI patients were in the age group 21-40 years (35, $54.7 \%)$. The mean age of the UTI patients was $36.62 \pm 17.4$ years with a range of $9-73$ years.

Table 1a. Distribution of socio-demographic characteristics of patients with UTI according to isolates

\begin{tabular}{|c|c|c|c|c|c|c|c|}
\hline \multirow{2}{*}{$\begin{array}{l}\text { Characteristics } \\
\mathrm{n}=64\end{array}$} & \multicolumn{7}{|c|}{ Isolates } \\
\hline & E. coli $\mathrm{n}(\%)$ & $\begin{array}{l}\text { S. } \\
\text { saprophyticus } \\
\mathrm{n}(\%)\end{array}$ & $\begin{array}{l}\text { Enterobacter } \\
\mathrm{n}(\%)\end{array}$ & Klebsiella $\mathrm{n}(\%)$ & $\begin{array}{l}\text { Providencia } \\
\mathrm{n}(\%)\end{array}$ & Candida $\mathrm{n}(\%)$ & Others $\mathrm{n}(\%)$ \\
\hline \multicolumn{8}{|l|}{ Sex } \\
\hline Female & $15(23.4)$ & $8(12.5)$ & $4(6.3)$ & $2(3.1)$ & 0 & $8(12.5)$ & $11(12.5)$ \\
\hline Male & $5(7.8)$ & $1(1.6)$ & $1(1.6)$ & $3(4.7)$ & $1(1.6)$ & $1(1.6)$ & $4(6.3)$ \\
\hline \multicolumn{8}{|c|}{ Age group (years) } \\
\hline $0-20$ & $5(7.8)$ & $1(1.6)$ & 0 & $2(3.1)$ & 0 & 0 & 0 \\
\hline $21-40$ & $10(15.6)$ & $6(9.4)$ & $4(6.3)$ & $2(3.1)$ & $1(1.6)$ & $3(4.7)$ & $9(14.0)$ \\
\hline $41-60$ & $3(4.7)$ & $2(3.1)$ & $1(1.6)$ & $1(1.6)$ & 0 & $1(1.6)$ & $4(6.3)$ \\
\hline $61-80$ & $2(3.1)$ & 0 & 0 & 0 & 0 & $5(7.8)$ & $2(3.1)$ \\
\hline
\end{tabular}


Table 1b Distribution of socio-demographic characteristics of patients with UTI according to presenting complaints

\begin{tabular}{|c|c|c|c|c|c|c|}
\hline \multirow{2}{*}{$\begin{array}{l}\text { Characteristics } \\
\mathrm{n}=64\end{array}$} & \multicolumn{6}{|c|}{ Presenting complaints } \\
\hline & Polyuria $\mathrm{n}(\%)$ & $\begin{array}{l}\text { Burning } \\
\text { sensation } \mathrm{n}(\%)\end{array}$ & $\begin{array}{l}\text { Painful urination } \\
\mathrm{n}(\%)\end{array}$ & $\begin{array}{l}\text { Lower } \\
\text { abdominal pain } \\
\mathrm{n}(\%)\end{array}$ & Fever $\mathrm{n}(\%)$ & $\begin{array}{l}\text { General body } \\
\text { pains } \mathrm{n}(\%)\end{array}$ \\
\hline \multicolumn{7}{|l|}{ Sex } \\
\hline Female & $27(42.2)$ & $\begin{array}{l}19(29.7) \\
\end{array}$ & $13(20.3)$ & $18(28.1)$ & $8(12.5)$ & $15(23.4)$ \\
\hline Male & $12(18.8)$ & $15(23.4)$ & $27(42.2)$ & $6(9.4)$ & $12(18.8)$ & $10(15.6)$ \\
\hline \multicolumn{7}{|c|}{ Age group (years) } \\
\hline $0-20$ & $5(7.8)$ & $1(1.6)$ & $6(9.4)$ & $7(10.9)$ & $6(9.4)$ & $8(12.5)$ \\
\hline $21-40$ & $15(23.4)$ & $12(18.8)$ & $21(32.8)$ & $5(7.8)$ & $9(14.0)$ & $8(12.5)$ \\
\hline $41-60$ & $10(15.6)$ & $12(18.8)$ & $8(12.5)$ & $10(15.6)$ & $1(1.6)$ & $6(9.4)$ \\
\hline $61-80$ & $5(7.8)$ & $6(9.4)$ & $5(7.8)$ & $2(3.1)$ & $4(6.3)$ & $3(4.7)$ \\
\hline
\end{tabular}

Table 2 Antibiotic sensitivity and resistance pattern of isolated bacteria in UTI

\begin{tabular}{|c|c|c|c|c|c|c|c|c|c|c|}
\hline \multirow{3}{*}{ Antibiotic } & \multicolumn{10}{|c|}{ Isolates } \\
\hline & \multicolumn{2}{|c|}{$\begin{array}{l}\text { E. coli } \\
N=20 n(\%)\end{array}$} & \multicolumn{2}{|c|}{$\begin{array}{l}\text { S. saprophyticus } \\
N=9 n(\%)\end{array}$} & \multicolumn{2}{|c|}{$\begin{array}{l}\text { Enterobacter } \\
\mathrm{N}=5 \mathrm{n}(\%)\end{array}$} & \multicolumn{2}{|c|}{$\begin{array}{l}\text { Klebsiella } \\
\mathrm{N}=5 \mathrm{n}(\%)\end{array}$} & \multicolumn{2}{|c|}{$\begin{array}{l}\text { Others } \\
\mathrm{N}=25 \mathrm{n}(\%)\end{array}$} \\
\hline & $\mathrm{R}$ & $\mathrm{S}$ & $\mathrm{R}$ & $\mathrm{S}$ & $\mathrm{R}$ & $\mathrm{S}$ & $\mathrm{R}$ & $\mathrm{S}$ & $\mathrm{R}$ & $\mathrm{S}$ \\
\hline Augmentin & $18(90)$ & $2(10)$ & $9(100)$ & 0 & $4(80)$ & $1(20)$ & $4(80)$ & $1(20)$ & $14(56)$ & $11(44)$ \\
\hline Ciprofloxacin & $6(30)$ & $14(70)$ & $2(22.2)$ & $7(77.8)$ & $1(20)$ & $4(80)$ & $1(20)$ & $4(80)$ & $3(12)$ & $22(88)$ \\
\hline Ceftriaxone & $12(60)$ & $8(300$ & $4(44.5)$ & $5(55.5)$ & $3(60)$ & $2(40)$ & $4(80)$ & $1(20)$ & $6(24)$ & $19(76)$ \\
\hline Gentamicin & $9(45)$ & $11(55)$ & $2(22.2)$ & $7(77.8)$ & $3(60)$ & $2(40)$ & $4(80)$ & $1(20)$ & $10(40)$ & $15(60)$ \\
\hline Piperacilin & $5(25)$ & $15(75)$ & $7(77.8)$ & $2(22.2)$ & $2(40)$ & $3(60)$ & $2(40)$ & $3(60)$ & $6(24)$ & $19(76)$ \\
\hline Amikacin & $2(10)$ & $18(90)$ & 0 & $9(100)$ & $2(20)$ & $4(80)$ & 0 & $5(100)$ & 0 & 100 \\
\hline Nitrofurantoin & $3(15)$ & $17(85)$ & 0 & $9(100)$ & $3(60)$ & $2(40)$ & $3(60)$ & $2(40)$ & $12(48)$ & $13(52)$ \\
\hline Nalidixic acid & $15(75)$ & $5(25)$ & $8(88.9)$ & $1(11.1)$ & $4(80)$ & $1(20)$ & $3(60)$ & $2(40)$ & $18(72)$ & $7(28)$ \\
\hline Ceftadizime & $8(40)$ & $12(60)$ & $7(77.8)$ & $2(22.2)$ & $2(40)$ & $3(60)$ & $4(80)$ & $1(20)$ & $18(72)$ & $7(28)$ \\
\hline Norfloxacin & $8(40)$ & $12(60)$ & $4(44.5)$ & $5(55.5)$ & $2(40)$ & $3(60)$ & $3(60)$ & $2(40)$ & $5(20)$ & $20(80)$ \\
\hline Tetracycline & $20(100)$ & 0 & $5(55.5)$ & $4(44.5)$ & $4(80)$ & $1(20)$ & $3(60)$ & $2(40)$ & $19(76)$ & $6(24)$ \\
\hline levofloxacin & $5(25)$ & $15(75)$ & $4(44.5)$ & $5(55.5)$ & $3(60)$ & $2(40)$ & $3(60)$ & $2(40)$ & 0 & $25(100)$ \\
\hline
\end{tabular}

$\mathrm{S}=$ Sensitive, $\mathrm{R}=$ Resistant

The most frequently isolated pathogen was $E$. coli (20, $31.2 \%)$, followed by $S$. saprophyticus $(9,14.1 \%)$ and Enterobacter $(5,7.8 \%)$. Candida species were isolated in $9(14.1 \%)$ patients, eight of whom were females. (Tables $1 \mathrm{a}$ and $1 \mathrm{~b})$.

The overall susceptibility profiles of the isolated pathogens are shown in Table 2. Most bacteria isolated $(52,94.5 \%)$ were sensitive to Amikacin, followed by Ciprofloxacin $(42,76.3 \%)$. The bacteria were least susceptible to Augmentin (10, 18.2\%), Nalidixic (13, $23.6 \%)$ acid and Tetracycline (13, 23.6\%) (Figure 1)
The most sensitive of the parameters was urine pus cells $>5$ WBC per HPF (94.4\%) and the least sensitive was the nitrite test (21.0\%). The nitrite test was however the most specific parameter with a specificity of $98.9 \%$, followed by the leukocyte esterase test (94.9\%) which had an accuracy of $91.1 \%$ (Table 3 ).

Significantly higher proportion of UTI patients reported that they had experienced polyuria $(\mathrm{p}=0.002)$, burning sensation upon passing urine $(\mathrm{p}=0.020$ and painful urination $(\mathrm{p}=0.038)$ as compared to non-UTI subjects (Table 4)

Table 3 Comparison of urinalysis parameters with urine culture in the detection of UTI

\begin{tabular}{|l|l|l|l|l|l|}
\hline Screening test & Sensitivity (\%) & Specificity (\%) & $\begin{array}{l}\text { Positive } \\
\text { predictive value } \\
(\%)\end{array}$ & $\begin{array}{l}\text { Negative predictive } \\
\text { value (\%) }\end{array}$ & Accuracy (\%) \\
\hline Nitrite & 21.0 & 98.9 & 80.0 & 84.5 & 85.9 \\
\hline Leukocyte esterase & 57.6 & 94.9 & 74.2 & 94.4 & 91.1 \\
\hline Urinary Pus Cell Count $\geq 5 / \mathrm{hpf}$ & 94.4 & 75.0 & 43.0 & 98.5 & 77.9 \\
\hline
\end{tabular}


Table 4 Presenting complaints of suspected UTI patients and the results of their urine analysis and urine culture

\begin{tabular}{|l|l|l|l|l|l|l|}
\hline \multicolumn{2}{|l|}{} & Urine culture & $\begin{array}{l}p \text { - } \\
\text { values }\end{array}$ & \multicolumn{3}{l|}{ Urine Analysis Parameters } \\
\hline Presenting complaints & $\begin{array}{l}\text { Positive } \\
(\mathrm{N}=64) \\
\mathrm{n}(\%)^{*}\end{array}$ & $\begin{array}{l}\text { Negative } \\
\mathrm{N}=149) \\
\mathrm{n}(\%)\end{array}$ & $\begin{array}{l}\text { Nitrite positive } \\
(\mathrm{N}=10) \mathrm{n}(\%)\end{array}$ & $\begin{array}{l}\text { Leukocyte } \\
\text { esterase positive } \\
(\mathrm{N}=35) \mathrm{n}(\%)\end{array}$ & $\begin{array}{l}\text { Urinary } \\
\text { Cell Count } \geq 5 / \\
\mathrm{hpf} \\
(\mathrm{N}=79) \mathrm{n}(\%)\end{array}$ \\
\hline Polyuria & $35(54.6)$ & $49(32.9)$ & 0.002 & $8(80)$ & $5(14.3)$ & $46(58.2)$ \\
\hline Burning sensation & $34(53.1)$ & $54(36.2)$ & 0.028 & $3(30)$ & $22(62.9)$ & $14(17.70$ \\
\hline Painful urination & $40(62.5)$ & $70(47.0)$ & 0.038 & $4(40)$ & $30(85.7)$ & $69(90.8)$ \\
\hline Lower abdominal pain & $24(37.5)$ & $49(32.9)$ & 0.515 & $5(50)$ & $11(31.4)$ & $15(19.0)$ \\
\hline Fever & $20(31.5)$ & $60(40.3)$ & 0.212 & 0 & $4(11.4)$ & $12(15.2)$ \\
\hline General body pains & $25(39.0)$ & $54(36.2)$ & 0.696 & 0 & $3(8.6)$ & $8(10.1)$ \\
\hline
\end{tabular}

*patients with pure growth of a single bacteria species

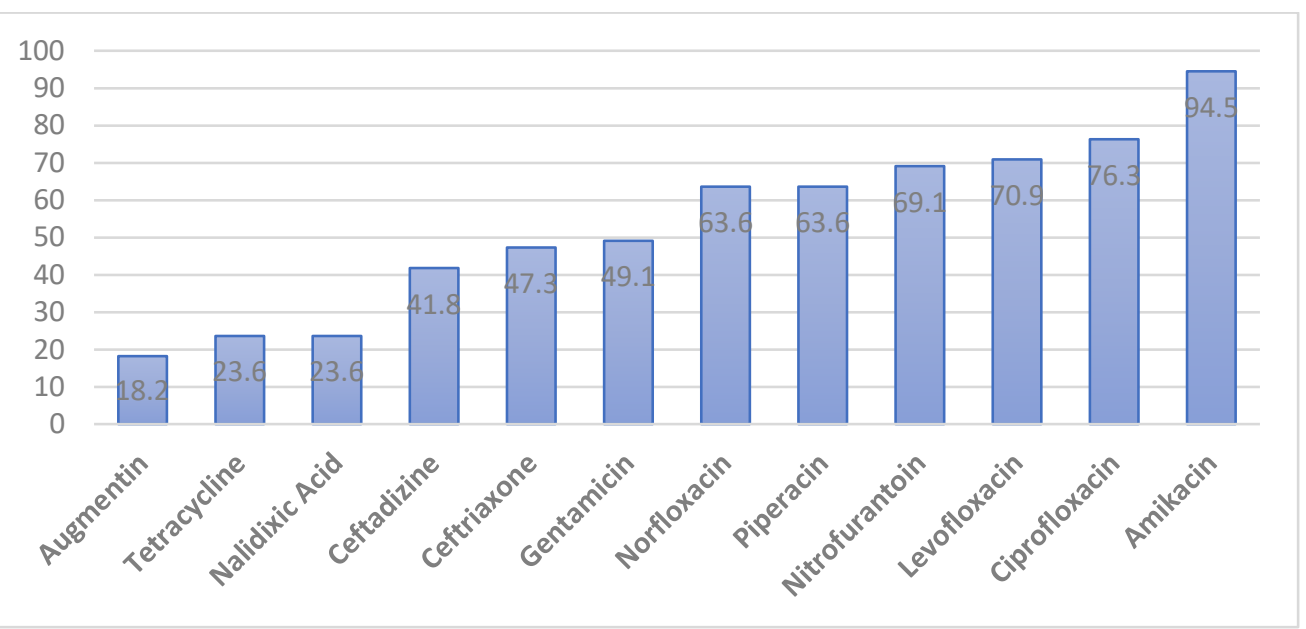

Figure 1 Overall uropathogen sensitivity to antibiotics

\section{DISCUSSION}

The prevalence of UTI among the study population was $30.0 \%$ which is relatively higher than the prevalence of $15.9 \%$ reported in an earlier study in Ghana ${ }^{15}$ and a rate of $6.3 \%$ found in an India study. ${ }^{21}$ The prevalence rate found in this study was however lower than the rate of $57.2 \%$ reported from Nigeria. ${ }^{22}$ The difference in the prevalence rates could be due to the difference in study designs, study sites, years between the studies and the definitions of UTI used in the study.

These earlier studies did not investigate fungal urinary tract infections. The incidence of UTI was higher in females $(71.9 \%)$ compared to males $(28.1 \%)$. Several studies conducted globally have reported similar differences in incidence of UTI between the genders. ${ }^{23}$ This has been attributed to the differences in the anatomy and physiology of the urinary and reproductive system of males and females. ${ }^{23}$ Evaluation for the presence of nitrites has been shown to be of value in the diagnosis of UTI.
The sensitivity and specificity of the nitrite test in this study were $21.0 \%$ and $98.9 \%$ respectively.

This finding is similar to that of some earlier studies that also found the nitrite test to be highly specific but generally insensitive. . $^{10}$

The high specificity and negative predictive value of the nitrite test in this setting indicate that a negative result virtually rules out UTI. This could probably be due to the fact that many of the uropathogens found in this study are capable of reducing nitrate to nitrites. ${ }^{6}$ The leukocyte esterase test had a sensitivity of $57.6 \%$ and a specificity of $94.9 \%$. Other studies had also found the leukocyte esterase test to be insensitive. ${ }^{10,24}$

The low sensitivity of the test limits its utility in diagnosing uncomplicated UTI in our setting. However a negative leukocyte esterase test result due to the high specificity and high negative predictive value could be used to screen for urine that do not need to be cultured. 
The high sensitivity (94.4\%) and low specificity (75.0\%) of pyuria ( $>5 \mathrm{WBC}$ per HPF) found in this study is similar to what was found in a review conducted by Simerville et al.. ${ }^{7}$

The high sensitivity of this test makes it important in the diagnosis of UTI in our setting. A positive test virtually confirms the disease even though there could be false positives. The test was also found to have a high negative predictive value $(98.5 \%)$. This means that a negative test result very nearly eliminates the presence of UTI. According to the American Academy of Family Physicians uncomplicated urinary tract infections diagnosed by positive leukocyte esterase and nitrite tests can be treated without culture. ${ }^{7}$

The study found a strong association between some clinical presentations and the occurrence of positive urine cultures. These patient' complaints were frequent urination, burning sensation associated with urination and pain on urination. These findings agree with what was reported by Thakre et al.. ${ }^{25}$ Typical history of UTI has been known to include pain on urination, frequency, urgency and haematuria. ${ }^{26}$

The findings of this study therefore suggest that patients who presents with frequent urination, burning sensation associated with urination and pain on urination are more likely to have UTI and could be considered for empirical treatment. Previous studies had shown that sensitivity based on a typical history is between $50 \%$ and $80 \%{ }^{26,27}$

E. coli was found to be the commonest pathogen responsible for UTI in our setting. Many previous studies conducted in different parts of the globe have also found E. coli as the most implicating pathogen isolated in UTI patients. ${ }^{28}$ S. saprophyticus was found to be the second leading cause of UTI in our setting. Similar findings have been observed by other workers..$^{29,30}$

It is the second most common causative agent of UTI in young women worldwide. ${ }^{30}$ The high incidence of $S$. saprophyticus urinary tract infection in this study brings to light its emerging prominence as an aetiological agent of UTI.

The most frequently isolated uropathogen $E$. coli was found to be highly sensitive to Amikacin (90\%), followed by Nitrofurantoin (85\%), Levofloxacin $(75 \%)$ and Ciprofloxacin (70\%). This high sensitivity of uropathogens to Amikacin had been observed by other workers as well. ${ }^{31} E$. coli was found to be most resistant to Tetracycline and Augmentin.

This correlates with the findings of some other studies. ${ }^{32}$ S. saprophyticus was most sensitive to Amikacin (100\%) and Nitrofurantoin (100\%). High sensitivity was also observed to Gentamicin (77.8\%), and Ciprofloxacin $(77.8 \%)$.

Similar sensitivity of S. saprophyticus to Gentamicin and Ciprofloxacin had been reported by earlier researchers. ${ }^{30}$ Overall, most isolates $(94.5 \%)$ were sensitive to Amikacin, followed by Ciprofloxacin (76.3\%).

This study revealed that Augmentin, Nalidixic acid and Tetracycline were virtually useless against the uropathogens as they were effective against only $18.2 \%$, $23.6 \%$ and $23.6 \%$ of all bacteria isolates respectively. Thus in our setting, the drug of choice for treating uncomplicated UTI is Amikacin followed by Ciprofloxacin. Amikacin is an aminoglycoside antibiotic, which is usually given by the intravenous and intramuscular routes. There is no oral form available as it cannot be absorbed orally. This limits its use among out patients. Its use for out-patients could also lead to the selection of resistant strains. Ciprofloxacin, which is a fluoroquinolone is available in oral and intravenous formulations. It can therefore be conveniently used as the first line treatment of uncomplicated UTI in the outpatient setting. The findings of this study thus support the recommendation of the Standard Treatment Guidelines of Ghana (2017) in the use of oral ciprofloxacin as the first line treatment of uncomplicated UTI. ${ }^{33}$

This study isolated Candida species in 9 patients. Some studies have reported increasing numbers of fungal UTI, particularly those caused by Candida spp, Aspergillus spp. and Cryptococcus neoformans. In a study conducted in a general hospital, positivity for Candida spp was found in 5\% of urine specimen and 10\% from a tertiary hospital. ${ }^{34}$ Diabetics are known to be particularly prone to fungal UTI. ${ }^{35}$ This finding indicates that clinicians should give consideration to fungal UTI in our setting especially in patients with persistent symptoms after course of standard treatment. The main stay of treatment for symptomatic candiduria is fluconazole $200 \mathrm{mg}$ daily for 2 weeks. ${ }^{36}$

\section{CONCLUSION}

The prevalence of UTI in this study was high (30.0\%). Most isolates were sensitive to amikacin and ciprofloxacin. Our findings support the recommendation of the use of oral ciprofloxacin as the first line treatment of uncomplicated UTI by the Ghana Standard Treatment Guidelines (2017).

\section{REFERENCES}

1. Demilie T, Beyene G, Melaku S, Tsegaye W. Urinary bacterial profile and antibiotic susceptibility 
pattern among pregnant women in north west Ethiopia. Ethiop J Health Sci. 2012; 22(2): 121-128.

2. Schappert SM, Rechtsteiner EA. Ambulatory medical care utilization estimates for 2006. National health statistics reports; no. 8. Hyattsville, MD: National center for health statistics; 2008

3. The Health Sector in Ghana: Facts and Figures, 2015

4. Schmiemann G, Knieh, E, Gebhardt K, Matejczyk MM,Hummers-Pradier E. The diagnosis of urinary tract infection: a systematic review. DtschArztebl. Int. 2010; 107(21): 361-7

5. Schmiemann G, Gebhardt K, Matejczyk M, Hummers-Pradier E: DEGAM-LeitlinieNr. 1: Brennen beimWasserlassen - Update 2009. Düsseldorf: Omikron publishing 2009

6. Pappas PG. Laboratory in the diagnosis and management of urinary tract infections. Med Clin N Amer1991; 75:313-25.

7. Simerville A. Jeff, William C Maxted, John J Pahira. Urinalysis: a comprehensive review. Am Fam Physician 2005; 71:1153-62

8. Institute for the study of Urologic diseases. Accessed at www.imop.gr/en/urotools-normal-values on $6 / 7 / 18$

9. Murray PR, Smith TB, McKinney TC. Clinical evaluation of three urine screening tests. $J$ ClinMicrobiol1987; 25:467-70.

10. dos Santos JC, Weber LP, Perez LR. Evaluation of urinalysis parameters to predict urinary-tract infection. Braz J Infect Dis. 2007;11(5):479-481

11. Kerr JR. Antibiotic treatment and susceptibility testing. Journal of Clinical Pathology, 2005;58(8): 786-87.

12. Ashkenazi S, Eventov S, Samra Z, et al. Uropathogens of various childhood populations and their antibiotic susceptibility. PediatrInfec Dis J 1991; 10:742-746.

13. de Francesco MA, Giuseppe R, Laura P, Riccardo N, Nino M. Urinary tract infections in Brescia, Italy: Etiology of uropathogens and antimicrobial resistance of common uropathogens. Med SciMonit 2007; 13: 136-144.

14. Boye A, Siakwa PM, Boampong JN, Koffuor GA, Ephraim RKD, Amoateng P, et al. Asymptomatic urinary tract infections in pregnant women attending antenatal clinic in Cape Coast, Ghana. E3 J Med Res. 2012;1(6):74-83.

15. Gyasi-Sarpong CK, Ta-AngYenli EM, Idriss A, Arhin AA, Aboah K, Azorlaide R, Boaitey YA, Annan AA. Bacterial urinary tract infections among males with lower urinary tract obstruction at Komfo Anokye Teaching Hospital, Kumasi, Ghana, OJU, 2012;2,131-136

16. Afriyie DK, Gyansa-Lutterodt M, Amponsah SK, Asare G, Wiredu V, Wormenor E, Bugyei KA. Susceptibility pattern of uropathogens to ciprofloxacin at the Ghana police hospital. Pan Afr Med J. 2015; 22:87

17. Cheesbrough M. Medical laboratory manual for tropical countries. 2nd ed. England: ButterworthHeineman Ltd; 2006. Pages 62-70

18. Collee, J.G., Miles, R.S. and Watt, B. (1996) Tests for the Identification of Bacteria. In Collee, J.G., Marmion, B.P., Fraser, A.G. and Simmons, A., Eds., Mackie\&McCartney Practical Medical Microbiology, 14th Edition, Churchill Livingstone, New York, 131-151.

19. CLSI (2009a). Methods for Dilution Antimicrobial Susceptibility Tests for Bacteria that Grow Aerobically, 8th edn. Approved Standard M07-A8. Wayne, PA: Clinical and Laboratory Standards Institute.

20. CLSI (2009b). Performance Standards for Antimicrobial Susceptibility Testing, 20th Informational Supplement M100-S20. Wayne, PA: Clinical and Laboratory Standards Institute.

21. Kashef N, Djavid GE, Shahbazi S. Antimicrobial susceptibility patterns of community-acquired uropathogens in Tehran, Iran. JInfect Dev Ctries2010; 4: 202-206.

22. El-Mahmood AM, Atimi AT, Tirmidhi B, Mohammed A.Antimicrobial susceptibility of some quinolone antibioticsagainst some urinary tract pathogens in a tertiary hospital, Yola, Adamawa State, Nigeria. J Clin Med Res 2009; 1: 26-34

23. Hotchandani R, Aggarwal KK. Urinary tract infections in women, Indian J Clin Pract. 2012 (23) 187-192

24. Laosu-angkoon S. The sensitivity and specificity of a urine leukocyte esterase dipstick test for the diagnosis of urinary tract infection in the outpatient clinic of Rajavithi Hospital. J Med Assoc Thai. 2013; 96(7):849-53.

25. Thakre SS, Dhakne SS, Thakre SB, Thakre AD, Ughade SM, Kale P. Can the Griess nitrite test and a urinary pus cell count of $\geq 5$ cells per micro litre of urine in pregnant women be used for the screening or the early detection of urinary tract infections in rural India? J ClinDiag Res. 2012;6(9):1518-22.

26. Bent $S$, Saint $S$ : The optimal use of diagnostic testing in women with acute uncomplicated cystitis. Am J Med. 2002; 113 (Suppl 1A): 20-8.

27. Hummers-Pradier E, Koch M, Ohse AM, Heizmann WR, Kochen MM: Antibiotic resistance of urinary pathogens in female general practice patients. Scand J Infect Dis 2005; 37: 256-61.

28. Wilson ML, Gaido L. Laboratory Diagnosis of Urinary Tract Infections in Adult Patients Clin Infect Dis 2004; 38:1150-8

29. Rupp ME, Soper DE, Archer GL. Colonization of the female genital tract with Staphylococcus 
saprophyticus. J Clin Microbiol Infect. 1992; 30 (11):2975-9

30. Jhora ST, Paul S: Urinary tract Infections caused by Staphylococcus Saprophyticus and their antimicrobial sensitivity pattern in young adult women. Bangladesh J Med Microbiol 2011, 05(01):21-25.

31. Mirsoleymani SR, Salimi M, Shareghi Brojeni M, et al. Bacterial pathogens and antimicrobial resistance patterns in pediatric urinary tract infections: a fouryear surveillance study (2009-2012). Int J Pediatr 2014; 126142:1-6

32. Desai P, Ukey PM, Chauhan AR, Malik S, Mathur M. Etiology and antimicrobial resistance patterns of uropathogens in a hospital from suburb of Mumbai. Int J Biol Med Res 2012; 3: 2007-2012

33. Standard Treatment Guidelines of Ghana. Ministry of Health, $7^{\text {th }}$ Edition. 2017

34. Rivett AG, Perry JA, Cohen J. Urinary candidiasis: A prospective study in hospitalized patients. Urol Res. 1986;14(3):153-173.

35. Sobel JD, Vazquez JA. Fungal infections of the urinary tract. World J Urol. 1999;17(6):410-414.

36. Sobel JD, Fisher J, Kauffman CA. Guidelines for the treatment of fungal urinary tract infections. Urinogenital Infections: EAU- International Consultation on Urological Diseases; 2010.

Copyright (C) The Author(s). This is an Open Access article under the CC BY license. 